\title{
Pengaruh Fakor Sosial Ekonomi Petani terhadap Produksi Usahatani Jagung di Desa Lanaus Kecamatan Insana Tengah
}

\section{Patrigius Maumabe ${ }^{\mathrm{a}}$}

${ }^{a}$ Fakultas Pertanian, Universitas Timor, Kefamenanu, TTU - NTT, Indonesia.

\section{Article Info}

\section{Article history:}

Received in revised form 3 Agustus 2018 Accepted 8 September 2018

\section{DOI:}

https://doi.org/10.32938/ag.v3i4.302

\section{Keywords:}

Faktor Sosial Ekonomi

Usahatani

Jagung
Received 2 Mei 2018

\section{Abstrak}

Penelitian ini bertujuan untuk mengetahui 1) gambaran umum usahatani jagung; dan 2) faktor-faktor sosial ekonomi yang mempengaruh produksi usahatani jagung di Desa Lanaus Kecamatan Insana Tengah Kabupaten TTU. Penelitian dilaksanakan di Desa Lanaus Kecamatan Insana Tengah Kabupaten TTU pada bulan Oktober sampai bulan November 2017. Metode yang digunakan dalam penelitian ini adalah metode survei dimana data yang dikumpulkan terdiri dari data primer dan data sekunder. Populasi adalah semua petani responden yang berusahatani jagung di Desa Lanaus dengan jumlah $207 \mathrm{KK}$. Responden yang diambil 30 responden dengan pertimbangan responden yang berusahatani jagung lebih dari 10 tahun. Alat analisis yang digunakan adalah analisis deskriptif kualitatif dan regresi linear berganda Kelayakan model akan diuji menggunakan uji $\mathrm{F}$, koefisien determinasi $\left(\mathrm{R}^{2}\right)$, dan uji t. Hasil penelitian menunjukkan bahwa tahapan usahatani jagung di lokasi penelitian dilakukan melalui tahapan 1) persiapan lahan dan pengolahan lahan; 2) pemilihan benih; 3) penanaman; 4) penyiangan; 5) panen dan pasca panen. $73,8 \%$ produksi usahatani jagung di Desa Lanaus dijelaskan oleh luas lahan, pendidikan, pengalaman, jumlah tanggungan keluarga, umur, benih dan curahan tenaga kerja, sedangkan $26,2 \%$ produksi usahatani jagung dipengaruhi faktor lainnya, walaupun demikian secara simultan variabel-variabel tersebut tidak berpengaruh nyata terhadap produksi usahatani jagung di Desa Lanaus. Demikian juga secara parsial variabel luas lahan, pendidikan, pengalaman, jumlah tanggungan keluarga, umur, benih dan curahan tenaga kerja tidak berpengaruh nyata terhadap produksi usahatani jagung di Desa Lanaus.

\section{Pendahuluan}

Pembangunan pertanian di Indonesia pada umumnya berorientasi pada ketahanan pangan dan swasembada pangan. Sektor pertanian ini juga berperan sebagai roda penggerak bagi sektor-sektor lainnya dengan memanfaatkan potensi dari sektor pertanian, dalam hal ini bahan baku pertanian. Pembangunan pertanian bertujuan untuk selalu memperbaiki mutu hidup dan kesejahteraan manusia terutama petani, baik perorangan maupun masyarakat pada umumnya.

Menurut Zulfitriani \& Bangun, (2016) jagung merupakan komoditas pangan kedua setelah padi dan sumber kalori atau makanan pengganti beras. Banyak kegunaan dan keunggulan dari tanaman jagung yakni dijadikan sebagai tepung, makanan ringan, jagung rebus, jagung bakar, bahan baku pakan ternak serta mengandung karbohidrat yang sangat dibutuhkan oleh tubuh sehingga dapat meningkatkan permintaan untuk tanaman jagung. Hampir seluruh bagian tanaman dapat dimanfaatkan untuk keperluan manusia baik langsung maupun tidak langsung. Sejalan dengan perkembangan industri pengolahan jagung dan perkembangan sektor peternakan, permintaan akan jagung semakin cenderung meningkat.

Kabupaten TTU adalah bagian dari provinsi Nusa Tenggara Timur yan memiliki luas lahan kering 149.945 ha atau $57,17 \%$ dari total luas wilayah. Wilayah lahan kering begitu luas tentunya sangat berpotensi untuk mengembangkan tanaman jagung. Berdasarkan produktivitas lahan yang diperoleh terlihat bahwa produksi jagung di TTU masih sebesar 2.091 ton/ha, sementara secara nasional produksi jagung/ha adalah 4-6 ton.

Data BPS Kab. TTU, (2017) menunjukkan bahwa Kecamatan Insana Tengah merupakan salah satu sentra produksi usahatani jagung lokal yang ada di Kabupaten TTU yang terdiri dari 7 desa dengan luas wilayah $\pm 38,80 \mathrm{Km}$. Sistem pertanian di Desa Lanaus masih bersifat tradisional dan sangat menggantungkan keberhasilan pada kemurahan alam. Budidaya usahatan jagung penduduk di Desa Lanaus berada pada lahan kering dengan sistem pengolahan musiman. Produksi jagung pada tahun 2012 luas lahan 47 ha produksi sebesar 63 ton dan produktivitasnya 1,36 ton/ ha, tahun 2013 luas lahan 48 ha produksi sebesar 54 ton dan produktivitasnya 1,12 ton/ ha, tahun 2014 luas lahan 45 ha produksi sebesar 60 ton dan produktivitasnya 1,33 ton/ha, tahun 2015 luas lahan 50 ha produksi sebesar 20 ton dan produktivitasnya 0,4 ton/ ha, tahun 2016 luas lahan 50 ha produksi 25 ton dan produktivitasnya 0,5 ton/ha. Di lihat dari perkembangan produksi usahatani jagung menurun karena curah hujan pada tahun 2016 tidak memadai.

Petani jagung sebagai manajer sekaligus sebagai pekerja dalam berusahatani jagung perlu memahami dengan benar dan baik tentang bagaimana berusahatani jagung sehingga hasil yang diharapkan bisa seoptimal mungkin. Usahatani jagung merupakan aktivitas produksi dibidang pertanian yang menghasilkan produk atau output berupa hasil-hasil pertanian. Produks usahatani jagung lokal di Desa Lanaus mengalami fluktuasi, hal ini diduga adanya faktor-faktor sosial ekonomi petani yang mempengaruhi produks jagung, oleh karena itu perlu dilakukan penelitian dengan topik "Pengaruh Faktor Sosial Ekonomi Petani terhadap Produksi Usahatani Jagung di Desa Lanaus Kecamatan Insana Tengah ”. Penelitian ini bertujuan untuk mengetahui 1) gambaran umum usahatani jagung; dan 2) faktor-faktor sosial ekonomi yang mempengaruhi produksi usahatani jagung di Desa Lanaus Kecamatan Insana Tengah Kabupaten TTU

\section{Metode}

Penelitian dilaksanakan di Desa Lanaus Kecamatan Insana Tengah Kabupaten TTU pada bulan Oktober sampai bulan November 2017. Metode yang digunakan dalam penelitian ini adalah metode survei dimana data yang dikumpulkan terdiri dari data primer dan data sekunder. Data primer diperoleh melalui observasi dan wawancara langsung dengan petani sedangkan data sekunder diperoleh dari lembaga-lembaga terkait dengan penelitian ini berupa monografi kecamatan, keadaan umum pertanian, dan data-data yang menunjang dalam pertanian.

Populasi adalah semua petani responden yang berusahatani jagung di Desa Lanaus dengan jumlah $207 \mathrm{KK}$. Teknik pengambilan sampel dilakukan dengan metode purposive simple random sampling menurut Bugin, (2005) yaitu, dari 207 KK yang diambil 30 responden dengan pertimbangan responden yang berusahatani jagung lebih dari 10 tahun. Pengamatan dan konsep pengukuran meliputi:

a. Identitas responden yang meliputi nama, umur (tahun), jenis kelamin (L/P) jumlah tanggungan keluarga (jiwa), tingkat pendidikan (formal/non formal); b. Gambaran umum usahatani jagung yang meliputi persiapan dan pengolahan lahan, pemilihan beni, penanaman, penyiangan, panen dan pasca panen;

c. Luas lahan garapan yang ditanami jagung (are);

d. Benih yakni jumlah benih yang digunakan dalam berusahatani jagung $(\mathrm{kg})$; e. Pengalaman usahatani yakni lamanya petani melakukan usahatani jagung (tahun);

f. Produksi yakni hasil yang diperoleh petani dalam 1 kali musim tanam $(\mathrm{kg})$; dan

g. Tenaga kerja yakni jumlah curahan tenaga kerja yang dibutuhkan dalam

Untuk mengetahui tujuan pertama gambaran umum usahatani jagung di Desa Lanaus Kecamatan Insana Tengah menggunakan metode analisi deskriptif kualitatif sesuai panduan Sugiyono, (2006) sedangkan untuk mengetahui pengaruh faktor sosial ekonomi petani terhadap produksi usahatan jagung di Desa Lanaus Kecamatan Insana Tengah digunakan analisis regresi linear sesuai petunjuk Gujarati \& Porter, (2009) dengan formula $Y=\beta o+\beta_{1} X_{1}$ $+\beta_{2} X_{2}+\beta_{3} X_{3}+\beta_{4} X_{4}+\beta_{5} X_{5}+\beta_{6} X_{6+} \beta_{7} X_{7}+\varepsilon$ dimana:
$\mathrm{Y} \quad$ : Produksi Jagung $(\mathrm{kg})$
ßo : Intersep
$\beta_{1}-\beta_{7}$ : Koefisien regresi dan variabel bebas
$\mathrm{X}_{1} \quad$ : Luas Lahan (are)
$\mathrm{X}_{2}$ : Tingkat pendidikan formal/non formal (tahun)
$\mathrm{X}_{3}$ : Pengalaman Usahatani (tahun)
$\mathrm{X}_{4} \quad$ : Jumlah tanggungan keluarga (orang)
$\mathrm{X}_{5}$ : Umur petani (tahun)
$\mathrm{X}_{6} \quad$ : Benih (kg)
$\mathrm{X}_{7} \quad$ : Curahan Tenaga Kerja (HKO)
$\varepsilon \quad$ : Variabel Pengganggu
Se(bi) : Simpangan baku

Analisis data dilakukan menggunakan bantuan aplikasi SPSS.16 yang dilakukan sesuai petunjuk Santoso, (2008). Kelayakan model akan diuji menggunakan uji F, koefisien determinasi $\left(\mathrm{R}^{2}\right)$, dan uji t. Pengujian untuk pengambilan keputusan dilakukan dengan tingkat kepercayaan $95 \%(\alpha 5 \%)$. Uj $\mathrm{F}$ dilakukan untuk mengetahui pengaruh seluruh variabel bebas (X) secara simultan terhadap variabel tetap (Y) dengan kaidah pengambilan keputusan jika nilai signifikansi (Sig.) $<0,005(\alpha$ 5\%) maka $X$ berpengaruh secara nyata terhadap Y, sebaliknya jika nilai signifikansi (Sig.) $>0,005(\alpha 5 \%)$ maka X tidak berpengaruh nyata terhadap $Y$. Uji t dilakukan untuk mengetahui pengaruh variabel bebas $(\mathrm{X})$ secara parsial terhadap variabel tetap $(\mathrm{Y})$ dengan kaidah pengambilan keputusan jika nilai signifikansi (Sig.) $<0,005(\alpha$ 5\%) maka X berpengaruh secara nyata terhadap Y, sebaliknya jika nilai signifikansi (Sig.) $>0,005(\alpha 5 \%)$ maka $X$ tidak berpengaruh nyata terhadap $\mathrm{Y}$. usahatani jagung (HKO). 


\section{Hasil dan Pembahasan}

\subsection{Deskripsi Usahatani Jagung}

Usahatani jagung yang dilakukan oleh petani desa Lanaus meliputi beberapa tahapan kegiatan yaitu persiapan lahan dan pengolahan lahan, persiapan benih, penanaman, penyiangan, panen dan pasca panen. Budidaya jagung yang dilakukan pada awal musim hujan yakni antara bulan November dan Desember. Umumnya jagung dibudidayakan secara tumpang sari dengan tanaman semusim lainnya seperti kacang tali, kacang hijau, kacang tanah, ubi kayu dan lain-lain.

a. Persiapan Lahan dan Pengolahan Lahan

Persiapan lahan dan pengolahan lahan yang dilakukan oleh masyarakat Desa Lanaus biasanya pada musim kemarau yaitu bulan Agustus-Oktober Persiapan lahan dilakukan dengan cara sistem tebas bakar untuk membuka lahan baru dengan menggunakan parang dan menebang pohon yang besar menggunakan kapak serta membabat rumput-rumput liar di sekitar kebun lalu dikumpulkan untuk membakarnya. Pengolahan lahan yang lama dengan menggunakan linggis atau pacul dengan tujuan untuk menggemburkan tanah agar tanaman jagung dapat memerlukan aerasi dan drainase yang baik. Waktu yang dibutuhkan dalam persiapan dan pengolahan lahan adalah $\pm 1-2$ bulan tergantung dari luas lahan yang diolah dengan rata-rata curahan tenaga kerja 22,84 HKO.

b. Pemilihan Benih

Pemilihan benih yang dilakukan oleh masyarakat Desa Lanaus adalah jagung yang dipanen pada tahun lalu yang tersimpan di atas lumbung (Lopo) kemudian diambil dan dilakukan pemipilan dengan tujuan untuk memisahkan biji jagung yang baik dan yang kurang baik, biji jagung yang baik diambil untuk siap ditanam pada lahan yang sudah disiapkan. Benih jagung yang baik yaitu tidak terkena serangan hama dan penyakit. Rata-rata curahan tenaga kerja $0,48 \mathrm{HKO}$.

\section{c. Penanaman}

Penanaman dilakukan pada awal musim hujan yang berkisar antara bulan November - Desember. Kegiatan penanaman jagung di lokasi penelitian adalah secara tumpang sari yakni setiap lubang tanam ditanami lebih dari dua jenis tanaman seperti jagung, labu, kacang tali, kacang merah. Jagung ditanam dengan jarak 75 × $25 \mathrm{~cm}$ menggunakan linggis dan setiap lubang tanam diisi 3 4 biji jagung kemudian ditutup rapat dengan tanah. Waktu penanaman bervariasi sesuai dengan luas lahan pertanian. Waktu yang dibutuhkan untuk penanaman jagung adalah 2-3 hari sesuai dengan luas lahan petani. Rata-rata curahan tenaga kerja $3,95 \mathrm{HKO}$

\section{d. Penyiangan}

Penyiangan dilakukan oleh petani 1-2 kali tergantung dari kondisi gulma. Penyiangan pada tanaman jagung dapat dilakukan apabila tanaman sudah berumur 5 - 6 helai daun. Kegiatan ini dilakukan secara manual dengan menggunakan tajak (Tofa) dan pacul. Tujuan dari kegiatan penyiangan adalah untuk menekan pertumbuhan gulma agar tanaman jagung tumbuh dengan baik. Gulma atau rumput yang telah dicabut kemudian dikumpulkan dan ditumpuk di sekitar tanaman sehingga akan berubah menjadi kompos. Waktu yang dibutuhkan untuk penyiangan adalah \pm 1-2 minggu. Rata-rata curahan tenaga kerja 12,14 HKO

\section{e. Panen dan Pasca Panen}

Pemanenan tanaman jagung kira-kira mencapai umur panen 3-4 bulan setelah tanam. Pemanenan dilakukan apabila jagung sudah tua dan kuning mengering. Kegiatan pemanenan di lokasi penelitian dilakukan dengan cara manual yakni jagung dipatah kemudian dikumpulkan dan disusun dalam karung yang telah disiapkan oleh petani agar dibawa pulang ke rumah. Setelah pengangkutan, jagung disimpan pada tempat yang sudah disiapkan untuk diikat dan dijemur selama 2-3 hari dengan tujuan agar jagung betul-betul kering. Setelah itu jagung disimpan pada tempat penyimpanan yakni lumbung (Lopo). Rata-rata curahan tenaga kerja 8,40 HKO.

\subsection{Faktor-Faktor yang Mempengaruhi Produksi Usahatani Jagung}

Berdasarkan hasil analisis menggunakan regresi linear berganda sebagaimana dapat dilihat pada Tabel 1. diperoleh persamaan $\mathrm{Y}=325,609+$ $1,603 X_{1}-10,006 X_{2}+18,365 X_{3}+25,614 X_{4}+21,804 X_{5}+48,009 X_{6}-0,599 X_{7}$.

Tabel 1. Koefisien Regresi Secara Parsial

\begin{tabular}{|c|c|c|c|c|c|}
\hline \multirow{2}{*}{ Model } & \multicolumn{2}{|c|}{ Unstanardized Coefficients } & \multirow{2}{*}{$\begin{array}{c}\begin{array}{c}\text { Standardized } \\
\text { Coefficients }\end{array} \\
\text { Beta }\end{array}$} & \multirow{2}{*}{$\mathrm{t}$} & \multirow{2}{*}{ Sig. } \\
\hline & B & Std. Error & & & \\
\hline (Constant) & 325,609 & 521,642 & & 0,624 & 0,358 \\
\hline $\mathrm{X}_{1}$ & 1,603 & 8,722 & 0,124 & 0,184 & 0,856 \\
\hline $\mathrm{X}_{2}$ & $-10,006$ & 15,536 & $-0,067$ & $-0,644$ & 0,526 \\
\hline $\mathrm{X}_{3}$ & 18,365 & 15,630 & 0,551 & 1,858 & 0,253 \\
\hline $\mathrm{X}_{4}$ & 25,614 & 40,763 & 0,075 & 0,628 & 0,536 \\
\hline $\mathrm{X}_{5}$ & 21,804 & 17,394 & 0,574 & 1,254 & 0,223 \\
\hline $\mathrm{X}_{6}$ & 48,009 & 38,155 & 0,746 & 1,258 & 0,221 \\
\hline $\mathrm{X}_{7}$ & $-0,599$ & 2,472 & $-0,056$ & $-0,242$ & 0,811 \\
\hline
\end{tabular}

Kelayakan model dalam menjelaskan produksi usahatani jagung diketahui dari $\mathrm{R}^{2}$, uji $\mathrm{F}$ dan uji t yang diuraikan sebagai berikut:

a. Koefisien Determinasi $\left(\mathrm{R}^{2}\right)$

Berdasarkan Tabel 2. diketahui bahwa koefisien determinasi $\left(\mathrm{R}^{2}\right)$ memiliki nilai 0,801 tetapi menurut Santoso, (2013) untuk regresi dengan lebih dari dua variabel bebas digunakan Adjusted R Square sebagai koefisien determinasi sehingga digunakan nilai Adjusted R Square sebesar 0,738 yang berarti 73,8\% produksi usahatani jagung di Desa Lanaus dijelaskan oleh luas lahan, pendidikan, pengalaman, jumlah tanggungan keluarga, umur, benih dan curahan tenaga kerja, sedangkan $26,2 \%$ produksi usahatani jagung dipengaruhi faktor lainnya.

Tabel 2. Koefisien Determinasi $\left(\mathrm{R}^{2}\right)$

\begin{tabular}{ccccc}
\hline Model & $\mathrm{R}$ & $\mathrm{R}$ Square & $\begin{array}{c}\text { Adjusted R } \\
\text { Square }\end{array}$ & $\begin{array}{c}\text { Std. Error of the } \\
\text { Estimate }\end{array}$ \\
\hline 1 & $0,895^{\mathrm{a}}$ & 0,801 & 0,738 & 178.435 \\
\hline
\end{tabular}

\section{b. Pengaruh Secara Simultan}

Pengaruh luas lahan, pendidikan, pengalaman, jumlah tanggungan keluarga, umur, benih dan curahan tenaga kerja secara simultan terhadap produksi usahatani jagung dapat dilihat pada Tabel 3. Nilai signifikansi (Sig.) pada Tabel 3. sebesar 0,000 lebih kecil dari 0,005 ( $\alpha$ 5\%) maka dapat disimpulkan bahwa secara simultan luas lahan, pendidikan, pengalaman, jumlah tanggungan keluarga, umur, benih dan curahan tenaga kerja tidak berpengaruh nyata terhadap produksi usahatani jagung di Desa Lanaus.

Tabel 3. Anova Regresi Linear Berganda

\begin{tabular}{lccccc}
\hline \multicolumn{1}{c}{ Model } & Sum of Squares & df & Mean Square & F & Sig. \\
\hline Regression & 2823182.802 & 7 & 403311.726 & 12,667 & $0.000^{\mathrm{a}}$ \\
Residual & 700484.584 & 22 & 31840.208 & & \\
\hline Total & 3523666,667 & 29 & & & \\
\hline
\end{tabular}

\section{c. Pengaruh Secara Parsial}

Data pada Tabel 1. menjelaskan pengaruh parsial dari variabel luas lahan, pendidikan, pengalaman, jumlah tanggungan keluarga, umur, benih dan curahan tenaga kerja terhadap produksi usahatani jagung yang dapat diuraikan sebagai berikut:

- Luas Lahan $\left(\mathrm{X}_{1}\right)$

Nilai signifikasi (Sig.) dari variabel luas lahan sebesar 0,856 atau lebih besar dari $0,05(\alpha 5 \%)$ menunjukkan bahwa variabel luas lahan tidak berpengaruh nyata terhadap produksi usahatani jagung.

- Pendidikan $\left(\mathrm{X}_{2}\right)$

Nilai signifikasi (Sig.) dari variabel pendidikan sebesar 0,526 atau lebih besar dari $0,05(\alpha \quad 5 \%)$ menunjukkan bahwa variabel pendidikan tidak berpengaruh nyata terhadap produksi usahatani jagung. Petani dengan tingkat pendidikannya yang lebih rendah akan mempengaruhi daya serap petani terhadap tingkat adopsi teknologi yang diterima serta menyebabkan rendahnya produktivitas tenaga kerja dan sektor manajemen dalam pertanian.

$\circ \quad$ Pengalaman $\left(\mathrm{X}_{3}\right)$

Nilai signifikasi (Sig.) dari variabel pengalaman sebesar 0,253 atau lebih besar dari $0,05(\alpha 5 \%)$ menunjukkan bahwa variabel pengalaman tidak berpengaruh nyata terhadap produksi usahatani jagung. Hal ini dapat dijelaskan bahwa terjadi kemungkinan karena petani responden di daerah penelitian memiliki rata-rata pengalaman usahatani jagung sebesar 28,3 tahun sehingga petani tersebut akan sulit untuk menerima inovasi baru yang dapat meningkatkan produksi jagung. Petani sudah merasa diri lebih berpengalaman dan nyaman dengan kondisi usahatani yang dijalankan bertahun-tahun.

○ Jumlah Tanggungan Keluarga $\left(\mathrm{X}_{4}\right)$

Nilai signifikasi (Sig.) dari variabel jumlah tanggungan keluarga sebesar 0,536 atau lebih besar dari $0,05(\alpha 5 \%)$ menunjukkan bahwa variabel jumlah tanggungan keluarga tidak berpengaruh nyata terhadap produksi usahatani jagung. Hal ini sejalan dengan hasil penelitian Kune $d k k$., (2016) yang menyimpulkan bahwa faktor jumlah anggota keluarga responden berpengaruh tidak nyata terhadap efek inefisiensi teknis dalam berusahatani jagung dengan tingkat kesalahan $25 \%$.

○ $\operatorname{Umur}\left(\mathrm{X}_{5}\right)$

Nilai signifikasi (Sig.) dari variabel umur sebesar 0,223 atau lebih besar dari $0,05(\alpha 5 \%)$ menunjukkan bahwa variabel umur tidak berpengaruh nyata terhadap produksi usahatani jagung.

$\circ \operatorname{Benih}\left(\mathrm{X}_{6}\right)$

Nilai signifikasi (Sig.) dari variabel benih sebesar 0,221 atau lebih besar dari $0,05(\alpha 5 \%)$ menunjukkan bahwa variabel benih tidak berpengaruh nyata terhadap produksi usahatani jagung. Petani di Desa Lanaus menggunakan benih dalam jumlah yang berlebihan karena benih yang digunakan merupakan milik sendiri yang sudah disiapkan, hal ini diduga menyebabkan variabel benih tidak berpengaruh secara nyata terhadap produksi.

- Curahan Tenaga Kerja $\left(\mathrm{X}_{7}\right)$

Nilai signifikasi (Sig.) dari variabel curahan tenaga kerja sebesar 0,811 atau lebih besar dari $0,05(\alpha 5 \%)$ menunjukkan bahwa variabel curahan tenaga kerja tidak berpengaruh nyata terhadap produksi usahatani jagung. Kondisi ini 
terjadi karena tenaga kerja menggunakan waktu yang boros dan tenaga secara tidak efisien (misalnya waktu yang digunakan lebih banyak untuk duduk dan melakukan obrolan dibanding bekerja).

\section{Simpulan}

Tahapan usahatani jagung di lokasi penelitian dilakukan melalui tahapan 1) persiapan lahan dan pengolahan lahan; 2) pemilihan benih; 3) penanaman; 4) penyiangan; 5) panen dan pasca panen. $73,8 \%$ produksi usahatani jagung di Desa Lanaus dijelaskan oleh luas lahan, pendidikan, pengalaman, jumlah tanggungan keluarga, umur, benih dan curahan tenaga kerja, sedangkan 26,2\% produksi usahatani jagung dipengaruhi faktor lainnya, walaupun demikian secara simultan variabel-variabel tersebut tidak berpengaruh nyata terhadap produksi usahatani jagung di Desa Lanaus. Demikian juga secara parsial variabel luas lahan, pendidikan, pengalaman, jumlah tanggungan keluarga, umur, benih dan curahan tenaga kerja tidak berpengaruh nyata terhadap produksi usahatani jagung di Desa Lanaus.

\section{Pustaka}

BPS Kab. TTU 2017. Kecamatan Insana Tengah dalam Angka 2017. Kefamenanu: Badan Pusat Statistik Kabupaten TTU.

Bugin, H.M.B. 2005. Metodologi Penelitian Kuantitatif. Jakarta: Kencana. Gujarati, D.N. \& Porter, D.C. 2009. Basic Econometrics. McGraw-Hill Irwin.

Kune, S.J., Muhaimin, A.W. \& Setiawan, B. 2016. Analisis Efisiensi Teknis dan Alokatif Usahatani Jagung (Studi Kasus di Desa Bitefa Kecamatan Miomafo Timur Kabupaten Timor Tengah Utara). AGRIMOR, 1(01): 3-6.

Santoso, S. 2008. Panduan Lengkap Menguasai Spss 16. Jakarta: Elex Media Komputindo.

Santoso, S. 2013. Menguasai SPSS 21 di Era Informasi. Jakarta: Elex Media Komputindo.

Sugiyono, 2006. Metode Penelitian Kuantitatif, Kualitatif dan $R \& D$. Bandung: Alfabeta.

Zulfitriani, E. \& Bangun, P. 2016. Analisis Faktor-Faktor yang Mempengaruhi Pendapatan Petani Jagung di Kecamatan Stm Hulu Kabupaten Deli Serdang. Skripsi. Medan: Universitas Sumatera Utara. 